\title{
Influence of With Pair Jump Rope Training and Ladder Drill Model on Kids Athletic Improvement
}

\author{
Regina Septiria $^{1)}$, M. Subandowo ${ }^{2)}$, Ujang Rohman ${ }^{3)}$ \\ Program Magister Pedidikan Jasmani \\ 1, 2, 3Program Pascasarjana, Universitas PGRI Adi Buana Surabaya, Indonesia \\ Email: ${ }^{1}$ reginaseptiriapenor@gmail.com, ${ }^{2}$ subanindi@gmail.com, ${ }^{3}$ jankroh64@gmail.com
}

\begin{abstract}
This study aims to develop a variety of athletic sports learning through pair jump rope and ladder drill training models to improve the kids athletics of elementary school students. The method used was an experimental method through a quantitative approach with a randomized group-pretestposttest design research design. The population was 32 elementary school students with a sample of grade IV and $V$ students selected by stratified proportional sampling, divided into two groups, each given a pair jump rope model $\left(X_{1}\right)$ and ladder drill model $\left(X_{2}\right)$. The data collection technique used the Kids Athletics Test IAAF instrument which was analyzed using the $t$ and anava tests at the sig level. $\alpha=0.05$. The results of the analysis $t_{\text {count }}>t_{\text {Sig..0.05 }}\left(>\operatorname{sig}{ }_{0.05}\right.$ ) means that the pair jump rope training model and the ladder drill training model can improve the kids athletic abilities of elementary school students. Mean while, the analysis of variance test results for each element of kids athletic obtained $F_{\text {count }}>F_{\text {sig.0.05 }}(>$ sig 0.05 ), which means that there is a significant difference between the paired jump rope athletic training model and the ladder drill training model to improve the kids athletic of elementary school students.
\end{abstract}

Keywords: Pair Jump, Ladder Drill, Kids Athletic

\section{Pengaruh Latihan Model Lompat Tali Berpasangan dan Ladder Drill Terhadap Peningkatan Kids Athletic ABSTRAK}

Latar belakang penelitian ini adalah permasalahan belum bervariasinya pembelajaran atletik yang bersifat rekreatif dan inovatif di Sekolah Dasar, oleh karena itu penelitian ini bertujuan mengembangkan pembelajaran olahraga atletik yang variatif melalui model latihan lompat tali berpasangan dan ladder drill untuk meningkatkan kids athletics siswa Sekolah Dasar. Metode yang digunakan adalah metode eksperimen melalui pendekatan kuantitatif dengan desain secara randomized pretest-posttest design. Populasi adalah siswa Sekolah Dasar dan sampel siswa kelas $I V$ dan $V$ yang dipilih secara stratified proportional sampling dibagi menjadi dua yaitu kelompok model lompat tali berpasangan $\left(X_{1}\right)$ dan ladder drill $\left(X_{2}\right)$. Teknik pengumpulan data menggunakan instrumen Kids Athletics Test IAAF dianalisis menggunakan uji t dan anava pada taraf sig. $\alpha=$ 0.05 . Hasil analisis uji t ternyata > sigo.0s berarti model latihan lompat tali berpasangan dan ladder drill dapat meningkatkan kemampuan kids athletic siswa. Sedangkan hasil uji analisis varian setiap unsur kids athletic ternyata > sigo.os berarti ada perbedaan yang signifikan antara model latihan atletik lompat tali berpasangan dengan ladder drill terhadap peningkatan kids athletic siswa. Berdasarkan temuan penelitian, kedua model latihan tersebut dapat dijadikan alternatif model latihan yang variatif untuk mengembangkan olahraga atletik di sekolah.

Kata Kunci: lompat tali, ladder drill, kids athletic.

Info Artikel

Dikirim

Diterima

Dipublikasikan
: 13 Oktober 2020

: 5 November 2020

: 12 November 2020
(C) 2020 IKIP BUDI UTOMO MALANG

P-ISSN 2613-9421

E-ISSN 2654-8003

\footnotetext{
Alamat korespondensi: jankroh64@gmail.com Universitas PGRI Adi Buana Surabaya, Jl. Ngagel Dadi III No.3B/37, Ngagelrejo, Kec. Wonokromo, Kota SBY, Jawa Timur 60234, Indonesia
} 


\section{PENDAHULUAN}

Pembelajaran atletik yang telah dikenalkan sejak usia Sekolah Dasar secara langsung akan mempengaruhi kemampuan motorik (lokomotor, non lokomotor dan manipulative) yang sangat dibutuhkan dalam masa perkembangan dan pertumbuhan anak (Rumini, 2014). Untuk mengembangkan motorik anak ada 3 komponen dasar yang dominan antara lain otot, saraf dan otak. Dari ke 3 komponen motorik tersebut satu sama lain saling berkaitan dan melengkapi terhadap unsur lainnya terutama dalam mencapai keadaan kondisi motorik yang lebih sempurna (Syamsidah, 2018). Berkembangnya kemampuan motorik tersebut merupakan cermin adanya berbagai peningkatan gerak dalam diri anak saat berinteraksi dengan lingkungan yang menyebabkan otot-otot pada tubuh terkoordinasi secara interaktif melalui aktivitas gerak.

Perkembangan motorik anak akan berkembang apabila dalam proses pembelajaran PJOK di sekolah diberi variasi pembelajaran dengan menerapkan dan mengembangkan model pembelajaran yang dapat mengembangkan berbagai potensi dan kemampuan anak (Putra \& Bafirman, 2020). Materi pelajaran PJOK yang menerapkan pembelajaran tersebut diantaranya materi pelajaran cabang olahraga atletik. Materi cabang olahraga atletik di sekolah yang sudah dikembangkan dan diterapkan pada anak usia setingkat Sekolah Dasar saat ini adalah program olahraga atletik untuk anak-anak yang dinamakan kids athletic. Kids' athletics diciptakan oleh para ahli pendidikan jasmani dalam bentuk permainan yang salah satunya untuk merangsang anak atau memberikan motivasi pada anak dalam aktivitas gerak yang menyerupai pembelajaran atletik sesungguhnya (Rumini, 2014). Oleh karena itu tujuan kids athletics adalah mengenalkan cabang olahraga atletik sejak anak-anak masih usia dini yang bersifat menyenangkan dan memberikan pengalaman seorang anak yang dibawa sampai usia dewasa. Bila dilihat dari karakteristik gerakannya menurut (Rumini, 2014), kids athletics memiliki gerak dasar yang terdiri dari unsur lari, lompat dan lempar. Mengacu pada konsep tersebut, maka pengembangan kemampuan kids athletics anak harus melalui pendekatan latihan fisik yang memiliki karakteristik berupa gerak dasar motorik lari, lompat dan lempar (Petros et al., 2017). 
Model pelatihan atletik untuk mengembangkan kemampuan kids athletic tersebut diantaranya adalah model lompat tali berpasangan berbentuk gerak lompat vertikal dan model lompat menurut arah tangga (ladder drill) berbentuk gerak lompat horizontal. Beberapa hasil penelitian yang relevan terkait kedua model latihan tersebut diantaranya latihan lompat tali. Latihan lompat tali berpasangan adalah suatu item untuk bermain atau latihan fisik yang terdiri dari seutas tali yang terbuat dari jalinan karet gelang atau bahan sintetis dengan pegangan yang melekat pada setiap anak secara berpasangan dengan cara memutar tali tersebut, kemudian anak melompat diantara putaran tali dalam irama secara terus-menerus tanpa berhenti (Padmaswari et al., 2017). Efek yang ditimbulkan bermain lompat tali berpasangan dapat melatih otot-otot tungkai menjadi kuat, lentur, lincah serta melatih keseimbangan, agar rasa percaya diri anak dapat meningkat (Sari, 2015). Selain itu perkembangan motorik anak dapat ditingkatkan melalui permainan lompat tali berpasangan (Harsono, 2015), karena permainan lompat tali dapat berpengaruh terhadap kemampuan motorik kasar pada anak (Achmadi \& Lailiyyah, 2018) dan program lompat tali memiliki efek signifikan pada keterampilan motorik kasar siswa Sekolah Dasar (Pathurohman \& Wibowo, 2017). Mengacu pada pendapat tersebut dapat dirumuskan bahwa lompat tali berpasangan yang dilakukan dengan cara melompati rintangan berbentuk tali bertujuan untuk meningkatkan motorik dan aktivitas kontraksi otototot tungkai sehingga tubuh akan menjadi lentuk dan seimbang serta terkoordinasi.

Bentuk latihan lainnya untuk mengembangkan olahraga atletik anak selain model lompat tali berpasangan yaitu model tangga ketangkasan atau model ladder drill. Bentuk latihan ladder drill secara esensial menyerupai tangga, dimana bentuk latihan ini sangat baik untuk mengembangkan unsur kecepatan, kelincahan dan koordinasi tungkai secara menyeluruh (Chandrakumar \& Ramesh, 2015). Selain itu latihan ladder drill efeknya sangat signifikan terhadap kecepatan dan kelincahan, karena otot-otot tungkai berkontraksi secara terus menerus selama latihan ladder drill (Pratama et al., 2018), dimana latihan ladder drill adalah alat latihan kecepatan dan kelincahan berbentuk tangga terletak di atas permukaan tanah yang memiliki fungsi untuk mengontrol dan melatih kelincahan otot tungkat 
serta meningkatkan kecepatan (Rajendran, 2016) dan ladder drill merupakan latihan yang sangat baik untuk meningkatkan kelincahan dan kecepatan (Kusnanik \& Rattray, 2017).

Makna dari konsep latihan ladder drill dapat digunakan untuk melatih kecepatan tungkai dan untuk meningkatkan power otot tungkai karena dilakukan dengan berbagai lompatan. Ladder drill merupakan tangga latihan yang umumnya di gunakan untuk membantu anak melatih kecepatan dan kelincahan melalui koordinasi tungkai mengikuti arah tangga secara horizontal.

Mengacu pada konsep model lompat tali berpasangan dan ladder drill tersebut, dapat disimpulkan bahwa latihan model lompat tali berpasangan dapat digunakan untuk melatih komponen kelentukan, keseimbangan dan kekuatan otot tungkai serta koordinasi mata, lengan dan tungkai. Sedangkan latihan model ladder drill dapat digunakan untuk melatih mengembangkan kecepatan tungkai dalam berbagai lompatan dan juga untuk melatih mengembangkan power otot tungkai. Kedua model latihan tersebut secara gerak memiliki kesamaan dalam mengembangkan kemampuan motorik yaitu mengembangkan koordinasi fungsional antara sistem otot, saraf dan otak yang menghasilkan fungsi motorik seperti jalan, lari dan lompat.

Berdasarkan uraian di atas dan hasil observasi peneliti melalui pengamatan saat pembelajaran atletik di Sekolah Dasar diperoleh data bahwa proses pembelajaran atletik di Sekolah Dasar belum berjalan maksimal, karena media pembelajaran yang digunakan terlalu monoton sehingga kurang variatif dan inovatif yang menyebabkan siswa kurang motivasi dan percaya diri dalam mengikuti pembelajaran. Mengacu pada hal tersebut, peneliti berusaha menerapkan pembelajaran gerak dasar olahraga atletik yang menarik dan variatif melalui model latihan atletik lompat tali berpasangan dan ladder dril dengan tujuan mengembangkan kemampuan kids athletic siswa di sekolah. Oleh karena itu dari hasil pengamatan, peneliti meneliti mengenai model pelatihan atletik lompat tali berpasangan dan ladder drill sebagai media pelatihan atletik pada siswa Sekolah Dasar untuk meningkatkan kemampuan kids athletic. Keutamaan dalam penelitian ini adalah penerapan model latihan lompat tali berpasangan dan 
ladder drill yang relatif baru sebagai model pembelajaran kids athletic yang variatif dan inovatif

Permasalahan dalam penelitian ini antara lain mengenai; (1) Penerapan model latihan lompat tali berpasangan dan ladder dril pengaruh terhadap peningkatan kids athletic dan (2) Perbedaan penerapan model latihan lompat tali berpasangan dengan latihan ladder drill pengaruh terhadap peningkatan kids athletic. Latar belakang kedua permasalahan tersebut diperoleh dari hasil observasi melalui pengamatan peneliti, ditemukan bahwa proses pembelajaran atletik masih monoton karena pemberian model pembelajaran atletik kurang variatif, sehingga menyebabkan rendahnya motivasi siswa pada materi pelajaran atletik sebagai akibat kurang menarik dan minimnya pemilihan media yang digunakan. Proses pendidikan jasmani akan berhasil jika model pembelajaran sesuai dengan karakteristik kemampuan yang ingin dicapai (Putra \& Bafirman, 2020). Selain itu model kids' athletics dapat memotivasi siswa Sekolah Dasar untuk belajar track and field (Petros et al., 2017). Sedangkan tujuannya untuk mengetahui penerapan model latihan atletik di sekolah pengaruh terhadap peningkatan kids athletic, dan membuktikan apakah ada perbedaan model lompat tali berpasangan dengan model ladder drill terhadap peningkatan kids athletic siswa. Urgensi hasil eksperimen diharapkan dapat dijadikan acuan dan rekomendasi para guru PJOK bahwa model pelatihan atletik lompat tali berpasangan dan ladder dril dapat dijadikan materi dan media alternatif pelatihan atletik dalam meningkatkan kemampuan kids athletic siswa di Sekolah Dasar yang terdiri dari komponen lari (canga's escape dan formula one), lompat (frog jump) dan lempar (turbo throwing). Selain itu dengan meningkatnya kemampuan kids athletic siswa diharapkan cabang olahraga atletik semakin digemari oleh anak-anak di sekolah dasar dan banyak ditemukan bibit-bibit baru atlet cabang olahraga atletik.

\section{METODE}

Metode penelitian adalah metode eksperimen. Jenis penelitian adalah eksperimen lapangan dimana prinsip replikasi, randomisasi dan perlakuan semuanya terpenuhi (Sugiyono, 2017). Rancangan atau desain penelitian 
dilakukan secara acak pada tes awal dan tes akhir (Randomized Pretest and Post test Design) dengan bagan sebagai berikut:

$$
\begin{aligned}
& \mathrm{K}_{1}=\text { Pre-test: -------- Post-test } \\
& \mathrm{E}_{2} \\
& \mathrm{~K}_{2}=\text { Pre-test: ---------- Post-test }
\end{aligned}
$$

Populasi merupakan keseluruhan subyek penelitian. Populasi adalah siswa Sekolah Dasar Negeri (SDN) Sawahan IV Kecamatan Sawahan, Kota Surabaya. Sampel yang digunakan merupakan sebagian atau wakil populasi yang diteliti. Teknik pengambilan sampel secara proporsi berdasarkan strata (stratified proportional sampling). Sampel terpilih sebanyak 32 siswa kelas IV dan V SDN Sawahan IV Kecamatan Sawahan, Kota Surabaya yangmeliputi18siswa kelas IV dan 14 siswa kelas V. Penentuan sampel dibagi menjadi dua kelompok eksperimen yaitu kelompok model latihan lompat tali berpasangan $\left(\mathrm{K}_{1}\right)$ sebanyak 16 siswa dan kelompok model latihan ladder drill $\left(\mathrm{K}_{2}\right)$ sebanyak 16 siswa.

Teknik pengumpulan data menggunakan instrumen Kid's Athletics Test IAAF yang terdiri dari item tes: (1) Canga's Escape yaitu gerakan lari estafet dengan kombinasi lari cepat (sprint) dan melompati gawang., (2) Loncat Katak (frog jump) berupa lompat ke depan dengan dua kaki dari posisi squat., (3) Lempar Turbo (turbo throwing) berupa lempar lembing anak panah dengan satu tangan untuk mencapai jarak tertentu sejauh mungkin dan (4) Formula One yaitu berupa gerakan lari estafet dengan kombinasi lari sprint, lari gawang dan slalom (APSO, 2012).

Analisis data menggunakan program aplikasi SPSS versi 22. Teknik analisis melalui tahapan uji normalitas menggunakan Kolmogorov-Smirnov Test. Tes ini bertujuan untuk menguji apakah data yang diperoleh berdistribusi normal. Sedangkan uji homogenitas bertujuan untuk menguji apakah kedua sampel yang diambil mempunyai data varian yang sama (homogen). Selanjutnya data tes yang dinyatakan normal dan homogen, maka untuk mengetahui dan membuktikan pengaruh model latihan atletik dua kelompok sampel $\left(\mathrm{K}_{1}\right.$ dan $\left.\mathrm{K}_{2}\right)$ dianalisis dengan menggunakan analisis uji-t dan untuk menguji perbedaan dua mean kelompok (independent sample) menggunakan Anava satu jalur pada taraf signifikasi $(\alpha=0.05)$ atau sig.0.05 


\section{HASIL DAN PEMBAHASAN}

Hasil analisis uji normalitas dan homogenitas data kids athletics test yang terdiri dari item tes (1) Canga's Escape, (2) Frog Jump, (3) Turbo Throwing, (4) Formula One adalah sebagai berikut.

Tabel 1. Normalitas Data Kelompok Lompat Tali Berpasangan

\begin{tabular}{lccc}
\hline \multicolumn{1}{c}{ Item Tes } & \multicolumn{2}{c}{ Kolmogorov-Smirnov Test } & Sig.(0.05) \\
& Awal & Akhir & \\
\hline Kanga's Escape & 0.922 & 0.069 & 8.00 \\
Frog Jump & 0.386 & 0.933 & 8.00 \\
Turbo Throwing & 0.234 & 0.407 & 8.00 \\
Formula One & 0.924 & 0.921 & 8.00 \\
\hline
\end{tabular}

Sedangkan hasil uji normalitas data instrumen kids athletics test kelompok ladder drill.

Tabel 2. Normalitas Data Kelompok Ladder Drill

\begin{tabular}{lccc}
\hline \multicolumn{1}{c}{ Item Tes } & \multicolumn{2}{c}{ Kolmogorov-Smirnov Test } & \multirow{2}{*}{ Sig.(0.05) } \\
& Awal & Akhir & \\
\hline Kanga's Escape & 0.940 & 0.001 & 8.00 \\
Frog Jump & 0.647 & 0.908 & 8.00 \\
Turbo Throwing & 0.090 & 0.629 & 8.00 \\
Formula One & 0.746 & 0.989 & 8.00 \\
\hline
\end{tabular}

Hasil uji normalitas pada tabel 1 dan 2 ternyata nilai Kolmogorov-Smirnov Testdimana $\alpha=0.05$ dan $\mathrm{df}=15$ diperoleh nilai setiap item tes kids athletics kurang $\operatorname{Sig}_{(0.05)}(<0.05)$ berarti data setiap item tes kids athletics berdistribusi normal.

Selanjutnya homogenitas data dengan taraf signifikasi $(\alpha=0,05)$ atau sig.0.05data setiap item tes adalah sebagai berikut.

Tabel 3 Homogenitas Data Kelompok Lompat Tali Berpasangan

\begin{tabular}{lcc}
\hline \multicolumn{1}{c}{ Item Tes } & $\mathrm{F}$ & $\mathrm{F}_{\text {Sig.(0.05) }}$ \\
\hline Kanga's Escape & 0.371 & 2.39 \\
Frog Jump & 0.797 & 2.39 \\
Turbo Throwing & 0.890 & 2.39 \\
Formula One & 0.892 & 2.39 \\
\hline
\end{tabular}

Sedangkan hasil uji homogenitas data instrumen kids athletics test kelompok ladder drill. 
Tabel 4 Homogenitas Data Kelompok Ladder Drill

\begin{tabular}{lcc}
\hline \multicolumn{1}{c}{ Item Tes } & $\mathrm{F}$ & $\mathrm{F}_{\text {Sig.(0.05) }}$ \\
\hline Kanga's Escape & 0.371 & 2.39 \\
Frog Jump & 0.797 & 2.39 \\
Turbo Throwing & 0.890 & 2.39 \\
Formula One & 0.892 & 2.39 \\
\hline
\end{tabular}

Hasil uji homogenitas pada tabel 3 dan 4 nilai $F$ dengan $\alpha=0.05$ dan $\mathrm{df}$ pembilang dan penyebut $(15 ; 15)$ ternyata nilai $F_{\text {hitung }}$ lebih kecil dari $F_{\text {tabel }}$ $\left[<\mathrm{F}_{\text {sig.(0.05) }}\right]$ berarti data setiap item varian tes kids athletics adalah sama (homogen). Setelah data tes dinyatakan normal dan homogen, tahap berikutnya dilakukan uji hipotesis menggunakan analisis statistik uji-t dimana $\alpha=0.05$ dan df $=15$. Pengujian ini bertujuan untuk mengetahui dan membuktikan peningkatan kemampuan setiap unsur kids athletics siswa Sekolah Dasar setelah mengikuti kegiatan model pelatihan atletik lompat tali berpasangan dan ladder drill. Hasil penghitungan uji-t sebagai berikut.

Tabel 5.Hasil Peningkatan Model Latihan Lompat Tali Berpasangan

\begin{tabular}{lcc}
\hline \multicolumn{1}{c}{ Item Tes } & $\mathrm{t}$ & $\mathrm{t}_{\text {Sig.(0.05) }}$ \\
\hline Kanga's Escape & 1.900 & 1.753 \\
Frog Jump & 3.203 & 1.753 \\
Turbo Throwing & 6.924 & 1.753 \\
Formula One & 5.928 & 1.753 \\
\hline
\end{tabular}

Sedangkan hasil uji t instrumen kids athleticstest kelompok ladder drill.

Tabel 6. Hasil Peningkatan Model Latihan Ladder Drill

\begin{tabular}{lcc}
\hline \multicolumn{1}{c}{ Item Tes } & $\mathrm{t}$ & $\mathrm{t}$ Sig.(0.05) \\
\hline Kanga's Escape & 10,305 & 1.753 \\
Frog Jump & 4.805 & 1.753 \\
Turbo Throwing & 5.917 & 1.753 \\
Formula One & 5.209 & 1.753 \\
\hline
\end{tabular}

Hasil peningkatan pada tabel 5 dan 6 ternyata nilai uji-t setiap unsur kids athletics diperoleh $\mathrm{t}>$ sig. $_{.05}$, artinya model pelatihan atletik lompat tali berpasangan dan Ladder Drill menghasilkan kemampuan yang signifikan dalam meningkatkan setiap unsur kids athletics siswa Sekolah Dasar. Peningkatan kemampuan tersebut 
disebabkan adanya efek latihan yang dilakukan secara sistematik dan terprogram selama pelatihan. Efek latihan ini merupakan bentuk perlakuan secara kontinu dengan beban latihan secara intensitas bertahap meningkat. Latihan jasmani terutama bila dilakukan secara teratur telah terbukti meningkatkan kemampuan fisik serta daya tahan pelakunya (Harsono, 2015). Adanya kemampuan yang meningkat pada setiap unsur kids athletic ditimbulkan oleh efek latihan pada saat melakukan gerakan lompat secara vertikal (lompat tali) dan secara horizontal (ladder drill) yang melibatkan otot-otot rangka (muscular skeleton), karena bila dilihat dari karakteristik gerak dasar kids athletic adalah gerakan yang meliputi unsur lari, lompat dan lempar. Hal ini dikarenakan dalam kids athletic ada gerakan dasar seperti lari, lompat, lempar dapat dilakukan dan dilatih dalam suatu bentuk bermain (Gozzoli et al., 2012). Selain itu kids' athletics memiliki unsur gerak dasar lari, lompat, lempar. Unsur gerak dasar lari, lompat dan lempar gerakannya membutuhkan kemampuan motorik tubuh berupa gaya yang dihasilkan oleh adanya kontraksi otot-otot tubuh yang dapat merangsang unsur biomotorik pada tubuh seperti kekuatan, kecepatan, power, kelincahan, kelentukan, daya tahan dan keseimbangan tubuh (Rumini, 2014).

Karakteristik gerak dasar seseorang pada masa kanak-kanak, untuk mengembangkan dan meningkatkan kemampuan motoriknya dapat dilakukan melalui pendekatan latihan fisik, hal ini dikarenakan latihan fisik memiliki tujuan; (1) mengembangkan fisik yang bersifat multilateral. (2) merangsang dan memacu pertumbuhan dan perkembangan anak. (3) sebagai gerak dasar lokomotor, stabilitas dan gerak manipulatif (Rumini, 2014). Oleh sebab itu, perubahan tingkat kemampuan unsur kids athletic merupakan hasil proses latihan dalam bentuk bermain latihan lompat tali berpasangan dan ladder drill. Lompat tali berpasangan merupakan bentuk permainan yang dapat mengembangkan kemampuan motorik. Kemampuan motorik tersebut meliputi perkembangan gerak berupa aktivitas fisik seperti; berlari, berjinjit, melompat, bergantung, serta menjaga keseimbangan (Theodora, 2013). Sedangkan model latihan ladder drill merupakan bentuk gerakan lateral yang sangat baik untuk meningkatkan kecepatan, koordinasi, dan kelincahan secara menyeluruh (Gevat et al., 2012). Kids athletic merupakan cermin dari kemampuan dasar gerak atletik yang dapat mewujudkan kemampuan 
atletik yang beragam pada diri anak sehingga dapat mengembangkan motorik yang bersifat multilateral dalam bentuk gerakan berlari, melompat dan melempar. Untuk mengetahui perbedaan peningkatan kedua model latihan tersebut, maka dilakukan uji hipotesis perbedaan dua mean kelompok (independent sample) menggunakan Anava satu jalur dengan taraf signifikasi $(\alpha=0.05)$ atau sig.0.05

Tabel 7 Perbedaaan Peningkatan Variabel $\mathrm{X}_{1}$ dengan $\mathrm{X}_{2}$

\begin{tabular}{lcc}
\hline \multicolumn{1}{c}{ Item Tes } & $\mathrm{F}$ & $\mathrm{F}_{\text {Sig.(0.05) }}$ \\
\hline Kanga's Escape & 4.422 & 2.33 \\
Frog Jump & 2.522 & 2.33 \\
Turbo Throwing & 2.718 & 2.33 \\
Formula One & 3.030 & 2.33 \\
\hline
\end{tabular}

Mengacu tabel 7 di atas, dapat dilihat hasil uji analisis varian dengan $\alpha=0.05$ dan $\mathrm{df}=30$ diperoleh nilai $F_{\text {hitung }}$ lebih besar dari nila $\mathrm{F}_{\text {tabel }}(>$ Sig.0.05) artinya ada perbedaan peningkatan model pelatihan atletik lompat tali berpasangan $\left(\mathrm{X}_{1}\right)$ dengan model ladder drill $\left(\mathrm{X}_{2}\right)$ dalam meningkatkan kemampuan kids athletics siswa Sekolah Dasar (Y), seperti pada diagram dibawah ini

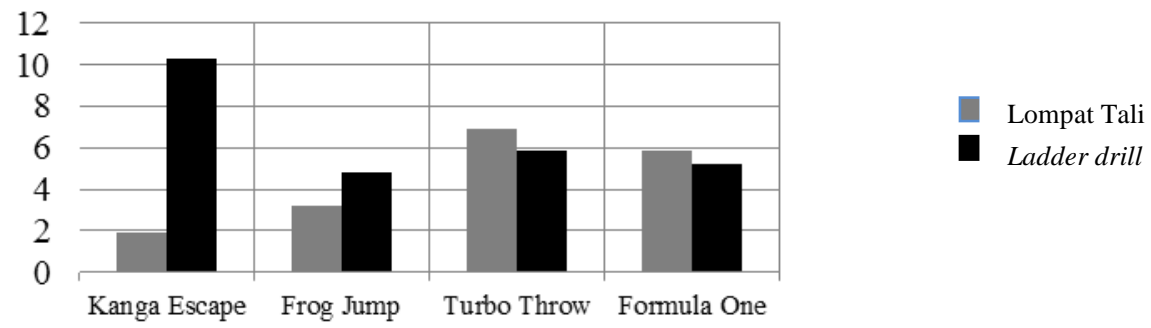

Gambar 1. Diagram Kids Athletics

Perbedaan peningkatan kemampuan unsur kids athletic yang dihasilkan antara model pelatihan atletik lompat tali berpasangan dengan model ladder drill, disebabkan oleh karakteristik gerakan model lompat tali berpasangan berbentuk gerak lompat vertikal sedangkan model ladder drill berbentuk gerak lompat horizontal. Gerakan lompat tali berpasangan ke arah vertikal membuat anak menjadi lebih kompleks dalam mempelajari cara melompatnya, karena dibutuhkan keterampilan anak dalam memainkannya. Selain itu bila sering dilakukan permainan ini membuat jaringan otot anak akan menjadi kuat, tangkas dan terlatih (Kamtini \& Kaban, 2016). Aspek gerak yang sangat dominan pada saat melakukan gerakan lompat tali ke arah vertikal merupakan cerminan 
kemampuan motorik anak dalam melakukan gerak dasar kids athletic. Sedangkan gerakan lompat horizontal dalam model pelatihan atletik ladder drills adalah cara yang dilakukan lebih sederhana dan lebih mudah untuk dipelajari bentuk keterampilan geraknya.

Gerakannya linear dan lateral tersebut apabila dikombinasikan gerakannya akan menjadi kompleks. Oleh karena itu model latihan dalam bentuk tangga atau ladder drills yang bersifat lateral dan sangat variatif merupakan salah satu latihan yang dapat meningkatkan kecepatan dan kelincahan dalam pembelajaran keterampilan gerak (Sethu, 2014) dan latihan ladder drill akan mempengaruhi kecepatan lari, kelincahan dan kekuatan otot tungkai (Jamil et al., 2015). Mengacu pada konsep tersebut, unsur gerak model pelatihan atletik lompat tali berpasangan dan ladder drill memiliki efek yang berbeda dalam meningkatkan kemampuan motorik anak. Ada tiga unsur untuk mengembangkan dan meningkatkan motorik anak yakni kekuatan tubuh anak, kelincahan dan keseimbangan (Samsiar, 2014). Beberapa konsep tersebut menjelaskan bahwa karakteristik gerakan lompat tali menghasilkan gerak yang lebih dominan pada unsur kondisi fisik seperti kekuatan, power, keseimbangan dan daya tahan tubuh. Sedangkan karakteristik gerakan ladder drill menghasilkan gerak yang lebih dominan pada unsur kondisi fisik seperti kecepatan, kelincahan, kekuatan otot kaki dan daya ledak otot tungkai atau daya eksplosif tubuh bagian tungkai.

Berdasarkan analisis gerak di atas, dapat disimpulkan bahwa adanya perbedaan hasil latihan model pelatihan atletik lompat tali berpasangan dan ladder drill terhadap peningkatan kids athletic disebabkan adanya efek latihan yang lebih dominan pada gerakan horizontal dibandingkan vertikal. Hal ini diperkuat oleh hasil penelitian yang menyatakan bahwa latihan ladder drill memberikan efek yang lebih meningkat dibandingkan latihan lompat tali dalam meningkatkan kecepatan dan kelincahan, serta memberikan efek yang lebih baik dibandingkan latihan lompat tali dalam meningkatkan kekuatan otot kaki (Pratama et al., 2018). Lebih dominan efek latihan ladder drill dibandingkan latihan lompat tali dikarenakan karakteristik gerak latihan ladder drill memiliki efek pada otot-otot kaki akan terus menerus berkontraksi selama latihan, sehingga akan menghasilkan perubahan fisiologis yang dominan pada peningkatan kecepatan, kekuatan dan 
kelincahan anak dibandingkan latihan lompat tali. Ada beberapa faktor yang saling berhubungan dalam meningkatkan motorik siswa diantaranya yaitu aspek kecepatan, kekuatan, kelincahan dan keseimbangan (Ghosh, S.S., \& Majunder, 2012). Faktor tersebut saling berhubungan dan sangat diperlukan untuk melakukan aktivitas olahraga. Oleh karena itu diharapkan pelatih dan guru PJOK dapat menerapkan latihan untuk meningkatkan kecepatan lari, kelincahan dan kekuatan otot tungkai para siswa dengan aktivitas olahraga lebih dominan ke arah horizontal (Kusuma \& Kardiawan, 2017).

Luang lingkup penelitian ini masih terbatas pada peningkatan kemampuan kids athletic siswa Sekolah Dasar, oleh karena itu untuk menambah khasanah penelitian ini agar lebih luas, maka perlu dikembangkan berdasarkan jumlah subjek yang diteliti dan dikemas dalam pengaturan (setting) gaya mengajar praktek (practice teaching style) yang lebih kreatif dan inovatif bagi seorang guru PJOK sehingga dapat mengembangkan berbagai kemampuan dan potensi siswa di sekolah.

\section{SIMPULAN}

Temuan penelitian secara konseptual ada dua indikator yaitu model latihan atletik lompat tali berpasangan dan model ladder drill sama-sama meningkatkan kemampuan kids athletic siswa, tetapi secara deskriptif ada perbedaan peningkatan kemampuan kids athletic antara pelatihan atletik model lompat tali berpasangan dengan model ladder drill pada siswa Sekolah Dasar. Dari ke tiga variabel $\left(\mathrm{X}_{1}, \mathrm{X}_{2}\right.$ dan $\left.\mathrm{Y}\right)$ dapat disimpulkan bahwa, (1) Penerapan kedua model pelatihan atletik meningkatkan kemampuan kids athletic siswa yang meliputi unsur lari, lempar dan lompat. (2) Pelatihan atletik model ladder drill lebih baik hasilnya dibandingkan pelatihan atletik model lompat tali berpasangan terhadap kemampuan kids athletic siswa Sekolah Dasar.

Mengacu pada temuan penelitian dan simpulan tersebut, saran yang dapat peneliti sampaikan adalah: (1) sebagai dasar capaian kemampuan kids athletic siswa, diharapkan media model pelatihan atletik lompat tali berpasangan dan ladder drill dapat dijadikan sebagai alternatif model pelatihan atletik yang variatif di Sekolah Dasar.(2) penerapan model pelatihan atletik lompat tali berpasangan 
dan model ladder drill diharapkan dapat dijadikan sebagai materi pelatihan atletik dalam pembelajaran Kids Athletic di sekolah guna meningkatkan kemampuan olahraga atletik siswa di Sekolah Dasar khususnya dan mengembangkan olahraga atletik di sekolah-sekolah sejenis umumnya.

\section{DAFTAR RUJUKAN}

Achmadi, \& Lailiyyah, L. (2018). Pengaruh Permainan Lompat Tali Terhadap Kemampuan Motorik Kasar Anak Kelompok B Tk Kartika Iv-9 Raider Surabaya. Wahana, 70(1), 63-70. https://doi.org/10.36456/wahana.v70i1.1570

APSO. (2012). Kid's Atletics. Jakarta: Pengurus Besar PASI.

Chandrakumar, N., \& Ramesh, C. (2015). Effect of Ladder Drill and SAQ Training on Speed and Agility Among Sports Club Badminton Players. Internat Ional Journal, 1(12), 527-529.

Gevat, C., Taskin, H., Arslan, F., Larion, A., \& Stanculescu, G. (2012). The Effects of 8-Week Speed Training Program on The Acceleration Ability and MaximumSspeed Running at 11 Years Athletes. Collegium Antropologicum, 36(3), 951-958.

Ghosh, S.S., \& Majunder, S. (2012). A Comparative Study on Agility and Dynamic Blance of Football Volleyball and Hockey Players. International Journal of Health, Physical Education and Computer Science in Sports, 8(1), 48-50.

Gozzoli, C., Locatelli, E., Massin, D., Bjorn, B. (2012). IAAF Kids'Athletics. A Team Event For Children. IAAF.

Harsono. (2015). Kepelatihan Olahraga, Teori dan Metodologi. In Jakarta:Remaja Rosdakarya.

Jamil, S. A., Aziz, N., \& Hooi, L. B. (2015). Effects of Ladder Drills Training on Agility Performance. International Journal of Health, Physical Education and Computer Science in Sports, 17(1), 17-25.

Kamtini, \& Kaban, D. (2016). Pengaruh Permainan Tradisional Lompat Tali Terhadap Perkembangan Motorik Kasar Anak Usia 5-6 Tahun Di TK Santa Lusia Medan T/A 2015/2016. Bunga Rampai Usia Emas, 2(1), 60-77.

Kusnanik, N. W., \& Rattray, B. (2017). Effect of Ladder Speed Run and Repeated Sprint Ability in Improving. Acta Kinesiologica, 11(1), 19-22.

Kusuma, A. C. A., \& Kardiawan, I. K. H. (2017). Effect of Ladder Drill Exercise on Speed, Surrounding, and Power Leg Muscle. E-Jurnal Physical 
Education, Sport, Health and Recreation, 6(3), 193-196. https://doi.org/10.15294/active.v6i3.17721

Padmaswari, G. A. D., Wirya, I. N., \& Magta, M. (2017). Penerapan Bermain Lompat Tali Untuk Meningkatkan Kemampuan Motorik Kasar Kelompok A TK Tunas Gama School. Jurnal Pendidikan Anak Usia Dini, 4(2), 1-10. https://doi.org/doi.org/10.23887/paud.v4i2.7811

Pathurohman, M., \& Wibowo, R. (2017). Meningkatkan Hasil Belajar Lompat Melalui Aktivitas Lompat Tali dengan Penerapan Gaya Practice. Jurnal Terapan Ilmu Keolahragaan. https://doi.org/10.17509/jtikor.v2i2.7985

Petros, B., Ploutarhos, S., Vasilios, B., Vasiliki, M., Konstantinos, T., Stamatia, P., \& Christos, H. (2017). The effect of IAAF Kids' Athletics on the physical fitness and motivation of elementary school students in track and field. Journal of Physical Education and Sport, 16(3), 883-896. https://doi.org/doi.org/10.7752/jpes.2016. 03139

Pratama, N. E., Mintarto, E., Kusnanik, N. W., \& Pratama1, N. E. (2018). The Influence of Ladder Drills And Jump Rope Exercise Towards Speed, Agility, And Power of Limb Muscle. IOSR Journal of Sports and Physical Education (IOSR-JSPE, 5(1), 22-29.

Putra, R. N., \& Bafirman, B. (2020). Efek Model Kids' Athletics Memberikan Nilai Tambah Dalam Meningkatkan Konsep Diri Siswa. Jurnal SPORTIF: Jurnal Penelitian Pembelajaran, 6(1), 69-79. https://doi.org/10.29407/js_unpgri.v6i1.13624

Rajendran, K. (2016). Effect of Ladder Training on Agility among College level Football Players. International Journal of Recent Research and Applied Studies, 3(4), 99-101.

Rumini, R. (2014). Pembelajaran Permainan Kids Atlhletics Sebagai Wujud Pengembangan Gerak Dasar Atletik Pada Anak-Anak. Journal of Physical Education Health and Sport, 1(2), 98-107. https://doi.org/10.15294/jpehs.v1i2.3208

Samsiar, N. (2014). Pengaruh Permainan Lompat Tali terhadap Kemampuan Motorik Kasar Anak di Kelompok B RA Al-Muhajirin Palu. Bungamputi, 2(9), 772-782.

Sari, P. . (2015). Upaya Meningkatkan Kemampuan Motorik Kasar Melalui Lompat Tali Pada Kelompok A TK ABA Di Ngabean I Tempel Sleman. Jurnal Pendidikan Guru PAUD, 5(4), 1-9.

Sethu, S. (2014). Comparison of plyometric training and ladder Training on Sprinting Speed, Vertical Explosive Power and Agility. Journal of Recent Research and Applied Studies, 1(1), 59-63.

Sugiyono. (2017). MetodePenelitian Kuantitatif, Kualitatif dan R\&D. Bandung: 


\section{PT Alfabet.}

Syamsidah. (2018). Development of Learning Tools of Problem-based Learning to Enhance Scientific Thinking Skills. Journal of Physics: Conference Series, 1028 (1). https://doi.org/10.1088/1742-6596/1028/1/012086

Theodora, W. (2013). Memahami Perkembangan Anak. Jakarta: PT Indeks. 